DOI: 10.22363/2312-9182-2019-23-2-415-434

\title{
Magic Folk Tales in Intersemiotic Translation
}

\author{
Natalia V. Shchurik, Vera E. Gorshkova \\ Irkutsk State University \\ 1, Karl Marx Str., Irkutsk, 664003, Russia
}

\begin{abstract}
The present paper examines intersemiotic translation of magic folk tales. Research objective is to show the structural identity of the surface structure which can be described as a sequence of plot elements ("functions") of fairy-tale characters; in semiotic terms it is explained by the existence of a universal matrix defining the law of genre. The authors go on to the cognitive-culturological aspect of fairy tales in terms of N. Chomsky. This research paper has clearly shown that "functions" of the surface structures correspond to plans, scenarios and frames of the deep structures, which differ in British and Russian magic fairy folk tales (wonder folk tales). Numbers and proper names are the main permanent elements of fairy tale narrative: on the level of the surface structures they connect the universal matrix of a fairy tale discourse organizing space and rhythm and at the level of the deep structures - they help to understand the main features of the national character. The study is based on 13 fairy-tale film corpus, under the common theme "Beauty and the Beast", film adaptations of the fairy tales "La Belle et la Bête" by J.-M. Leprens de Beaumont (1757) and "The Scarlet Flower" by S.T. Aksakov (1858). Hence, the analysis of the latter based on the works of R. Jacobson and W. Eco and understood by the authors as a kind of intersemiotic translation / interpretation that, on the one hand, proves universality of the proposed algorithm for studying fairy discourse in synchrony and diachrony. On the other hand, it plays the most important role in intersemiotic translation of diachronic aspect because it deals with changing the "integral model of reality", which is reflected, in particular, in changing the on-screen presentation / interpretation of certain aspects of the fairy-tale narrative. Finally, it is worth pointing out that the conclusions can be used to study plurality of film adaptation as a form of intersemiotic translation.
\end{abstract}

Keywords: Magic folk tales, deep and surface structure, film adaptation, intersemiotic translation, interpretation

For citation:

Shchurik, Natalia V., Gorshkova, Vera E. (2019). Magic Folk Tales in Intersemiotic Translation. Russian Journal of Linguistics, 23 (2), 415 — 434. doi: 10.22363/2312-9182-2019-23-2-415-434.

\section{Волшебные сказки в свете интерсемиотического перевода}

\author{
Н.В. Щурик, В.Е. Горшкова \\ Иркутский государственный университет \\ ул. Ленина, Иркутск, 8664025, Россия
}

\begin{abstract}
Аннотация
Статья посвящена интерсемиотическому переводу волшебных сказок. Цель статьи - показать структурную идентичность поверхностной структуры последних как отражающих последовательность функций сказочных героев, что в семиотическом плане объясняется существованием универ-
\end{abstract}


сальной матрицы, определяющей закон жанра. Адекватное представление проблемы потребовало обращения к когнитивно-культурологическому аспекту сказок в терминах Н. Хомского, позволяющему выявить соответствие функций поверхностной структуры сказок планам, сценариям и фреймам глубинной структуры, заметно различающимся, например, в британских и русских волшебных народных сказках, что находит свое отражение, в частности, в таких элементах сказочного нарратива, как числа и имена собственные, связывающие универсальную матрицу сказочного дискурса на уровне поверхностных структур, организуя пространство и ритм, а на уровне глубинных структур - помогающие понять основные черты национального характера. Материалом исследования послужили 13 фильмов-сказок, объединенных общей темой «Красавица и Чудовище», представляющих с собой экранизации сказок «La Belle et la Bête» Ж.-М. Лепренс де Бомон (1757 г.) и «Аленький цветочек» С.Т. Аксакова (1858 г.). Анализ означенных экранизаций, рассматриваемых авторами как разновидность интерсемиотического перевода/интерпретации с опорой на труды Р. Якобсона и У. Эко, с одной стороны, подтверждает универсальность предложенного алгоритма изучения сказочного дискурса в синхронии и диахронии, с другой - обозначает первостепенную важность для интерсемиотического перевода диахронического аспекта, влекущего за собой изменение «целостной модели действительности», что находит свое отражение, в частности, в изменении экранного представления/ интерпретации тех или иных аспектов сказочного нарратива. Сделанные выводы могут найти применение для исследования и обоснования множественности экранизаций как разновидностей интерсемиотического перевода.

Ключевые слова: волшебные сказки, глубинная и поверхностная структура, экранизация, интерсемиотический перевод, интерпретаиия

\section{Для цитирования:}

Щурик Н.В., Горшкова В.Е. Волшебные сказки в свете интерсемиотического перевода // Вестник Российского университета дружбы народов. Серия: Лингвистика = Russian Journal of Linguistics. 2019. T. 23. No 2. C. 415-434. doi: 10.22363/2312-9182-2019-23-2-415-434.

\section{ВВЕДЕНИЕ}

Есть огромный организм под названием Кино. В нем найдется место для любых историй.

А. Талал (Талал 2018: 392)

С развитием новых технологий уходящая в прошлое эпоха Гутенберга все стремительнее уступает место новым формам художественного представления. Не последнюю роль в этом процессе играет кинематограф, искусство сравнительно молодое, возникшее чуть более ста лет назад, с первых дней своего существования привлекшее внимание исследователей самых различных дисциплин как в плане специфики художественной формы, так и в плане раскрываемых возможностей интерпретации действительности.

Особое место в ряду кинематографических произведений занимают сказки, практически не подвергавшиеся научному анализу несмотря на свою популярность как в детской, так и во взрослой зрительской аудитории.

Кинематографическое представление сказок, их экранизация, может рассматриваться как отдельный тип интерсемиотического перевода в терминах Р. Якобсона, которому мы обязаны подразделению перевода на три типа:

1) внутриязыковой (интралингвистический) перевод или пересказ/переформулирование (rewording), то есть передача и/или интерпретация вербальных знаков с помощью других знаков того же языка;

2) межъязыковой перевод или собственно перевод - интерпретация вербальных знаков посредством знаков другого языка; 
3) межсемиотический (интерсемиотический) перевод или трансмутация, при котором вербальные знаки интерпретируются с помощью других знаковых систем, или наоборот (Якобсон 1978).

Расширяя круг рассматриваемых аспектов последнего, некоторые исследователи также относят к интерсемиотическому переводу интерпретацию неязыковых знаков собственно неязыковыми (живопись, скульптура) (интра-семиотический перевод в терминах Л.И. Раздобудько-Чович и Б. Човича) (Чович 2010: 29).

Внимательное ознакомление с концепцией Р. Якобсона позволяет исследователям сделать ряд важных выводов. Во-первых, что «эквивалентность перевода оригиналу не означает тождественности их содержания» (Комиссаров 2001: 223). Во-вторых, как отмечает У. Эко, «Якобсон показывает, что интерпретировать некий семиотический элемент - значит „переводить““ его в некий другой элемент (который, впрочем, может быть дискурсом во всей его полноте), и что благодаря такому переводу элемент, подлежащий интерпретации, творчески обогащается» (курсив наш - В.Г., Н.Щ.) (Эко 2006: 274). Обратим внимание на уточнение, приводимое исследователем в скобках. Именно таким элементом «во всей его полноте» и предстает экранное воплощение некоего текста, будь то текст художественный или семиотически осложненный кинотекст (Горшкова 2016, Горшкова, Лиханова 2016, Горшкова 2017). В своем труде под весьма символическим названием «Сказать почти то же самое. Опыты о переводе» У. Эко дает свое толкование термина Р. Якобсона, подчеркивая, что многие трансмутации являются переводами «в том смысле, что они вычленяют только один из уровней текста-источника и тем самым делают ставку на то, что именно этот уровень единственно важен для того, чтобы передать смысл оригинального произведения» (Там же: 401). И далее: «вычленить некие уровни - как раз и значит навязать собственную интерпретацию текста-источника» (выделено автором) (Там же: 402).

Приводимые замечания представляются чрезвычайно важными в контексте нашего исследования, целью которого является интерсемиотический перевод/интерпретация экранизаций волшебных сказок, в основе которого лежит сопоставительный анализ последних (см. ниже Раздел 3).

\section{1. ПОВЕРХНОСТНЫЕ И ГЛУБИННЫЕ СТРУКТУРЫ НАРОДНЫХ ВОЛШЕБНЫХ СКАЗОК}

«Как целое понимается из отдельного, но и отдельное может быть понято только из целого, имеет такую важность для данного искусства и столь неоспоримо, что уже первые же операции невозможно проделать без применения его, да и огромное число герменевтических правил в большей или в меньшей степени основывается на нем» (Шлейермахер 2018: 99). В свете означенного герменевтического принципа считаем возможным обращение к инструментарию когнитивной парадигмы в качестве первого шага к комплексному описанию особенностей перевода-интерпретации волшебных сказок*. В русле последней «лежащая в основе

* Собственно лингвистической основой исследования служит авторская модель лингво-семиотического анализа народной волшебной сказки, продолжающей цикл публикаций на данную тему (автореферат дис. кандидата филологических наук: Щурик Н.В. Опыт лингвосемиотического анализа народной волшебной сказки. Иркутск, 2007). 
глубинная структура, с ее абстрактной организацией языковых форм, „дана уму“, в то время как сигнал, с его поверхностной структурой, производится или воспринимается телесными органами. А трансформационные операции, связывающие глубинную и поверхностную структуры, являются действительными мыслительными операциями, выполняемыми умом» (Хомский 1972: 29). Данная идея Н. Хомского позволяет нам не только вывести наше исследование в семиотикокогнитивное пространство, но и изменить авторскую формулировку поверхностной и глубинной структур, инвертируя эти понятия (Щурик 2006: 365).

Что касается собственно семиотико-структурного аспекта, поверхностная структура определяет закон жанра и является универсальной матрицей: все волшебные сказки идентичны по своему строению и представляют собой последовательность функций сказочных героев. Аргументом в пользу сказанного может служить факт структурной однотипности фольклорных произведений (в нашем случае волшебных сказок) разных народов. А поскольку все волшебные сказки это метафорическое повествование о древнем ритуале инициации [Пропп 1998], то функции, выполняемые героями сказки, можно положить в основу матрицы сказочного нарратива.

Исследования В.Я. Проппа заложили основу для дальнейшего изучения сказочного нарратива. Особого внимания заслуживает подход Б. Кербелите, посвященный анализу элементарных сюжетов. Как пишет автор, «в один элементарный сюжет соединяются все события и ситуации, которые связаны с достижением одним героем (герой может быть коллективным, например братья) одной цели, независимо от их места в тексте. Таким образом, элементарный сюжет начинается с возникновения какой-то цели, появления недостачи или несоответствия и кончается достижением этой осознанной героем цели или другого, не предвиденного им результата, существенно меняющего его положение» (Кербелите 1980: 53). Соответственно, элементарные сюжеты определяют основную цель и конечный результат действий конкретного героя в определенной ситуации.

В противовес набору функций В.Я. Проппа Б. Кербелите предлагает пять элементарных сюжетов сказочного нарратива, которые могут как накладываться друг на друга, так и следовать один за другим. Приведем перечень этих сюжетов:

1) стремление к свободе от чужих или к господству над ними;

2) добывание средств существования или объектов, создающих удобство;

3) стремление к равноправному или к высокому положению в семье или обществе;

4) поиски невесты или жениха;

5) стремление к целостности и полноценности семьи.

Совмещение двух теорий позволяет построить универсальный алгоритм, который перекликается с герменевтическим подходом к анализу текста и одновременно отражает основные философские положения «полного гегелевского цикла» (Гегель 2006): деление на функции предполагает анализ от общего к частному, выявление общих элементарных сюжетов базируется на изучении сказочного нарратива от частного к общему. 
Схематично этот анализ можно представить следующим образом:

$$
[[[\mathrm{ABC} \uparrow-\downarrow Л]]] .
$$

Квадратные скобки отображают элементарные сюжеты, которые в свою очередь подразделяются на функции (А, В, С, Л). Данная схема наглядно демонстрирует универсальный характер поверхностной структуры сказочного нарратива и позволяет установить связь между функциями поверхностной структуры и планами глубинной структуры, которые не совпадают, к примеру, в британских и русских волшебных народных сказках.

Что касается глубинной структуры, в рамках когнитивного подхода последняя включает культуроориентированные сценарии, фреймы и составляющие их слоты. Непосредственно от фреймов и сценариев, определяющих действия сказочного героя, зависит достижение цели последнего, что позволяет выделить планы глубинных структур для последующего анализа. Именно в глубинных структурах сказочного дискурса закодированы культурно-специфические различия волшебных сказок, способствующие идентификации индивидуума в плане культурной принадлежности. Наиболее сильное влияние информация глубинных структур оказывает на детей в силу синкретизма их мышления, столь характерного для мышления мифологического. Слушая сказки, дети анализируют содержащуюся в ней информацию в поисках «ключей» к пониманию значения, поскольку «язык стал заключать в себе систему кодов, достаточных для передачи любой информации. Слово объединяет объекты в известные системы, иначе говоря, кодирует наш опыт» (Лурия 1979: 25-31).

В русле наших рассуждений необходимо развести понятия фрейм и сценарий. Д. Тэйлор определяет их в терминах статики и динамики: фреймы представляют собой статичные конфигурации знания, а сценарии - динамичную последовательность событий (Taylor 1995: 87). Другими словами, фрейм и сценарий отличаются по референциальному признаку: фрейм описывает факт, который может быть истолкован как предшествующее знание, а сценарий - событие, предстающее как знание новое.

Всесторонний анализ сказочного нарратива, с одной стороны, и сказочного дискурса, с другой, предполагает обращение к элементарным сюжетам поверхностной структуры, которым соответствуют планы глубинных структур. На уровне поверхностной структуры все волшебные сказки универсальны, сказочные сюжеты развиваются согласно определенной последовательности функций. Различие заключается в культурологическом смысле, который закодирован в глубинных структурах сказочного дискурса.

Фреймовый анализ позволяет не только интерпретировать цели и мотивы сказочных персонажей, но и выявляет основные культурологические маркеры, предопределяющие поведение индивида в культурной среде в дальнейшем.

На основе целей основных действующих лиц определяются мировые линии, которые позволяют прослеживать развитие возможных миров сказочных персонажей, поскольку элементарные сюжеты и планы имеют тенденцию перемещения из одного в другой в топологическом пространстве дискурса. В основе взаимодействия сюжетов и планов находится категория сказочного времени, которая позво- 
ляет героям, с одной стороны, «необыкновенным» образом перемещаться внутри сказочного дискурса, a, с другой стороны, создает особую ритмическую организацию текста.

Как видим, сказочный нарратив является сложной системой переплетения поверхностных и глубинных структур. Взаимодействие последних непосредственно обусловлено временным фактором. Предлагаемая ниже схема позволяет изучать дискурс народных волшебных сказок одновременно в синхронии и диахронии. Изучение сказочного нарратива в синхронии - это не что иное как анализ последовательности функций, а обращение к диахроническому аспекту предполагает исследование последовательного развития элементарных сюжетов во времени. Элементарные сюжеты поверхностной структуры и составляющие их функции расположены по оси X, а планы, сценарии и фреймы глубинной структуры разворачиваются по оси Ү. Означенная трехмерная схема наглядно демонстрирует, как актуализируются, развиваются и взаимодействуют параллельные миры героев.

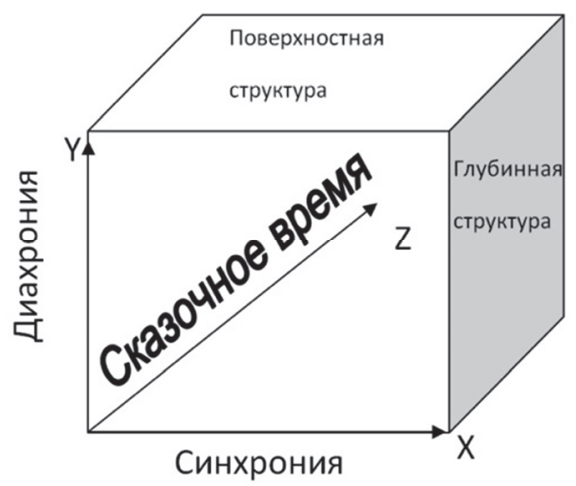

Схема 1. Сказочный нарратив в синхронии и диахронии

Особый интерес представляют функции сказочного нарратива, поскольку эти категории способны к линейному и нелинейному развитию. Образуя матрицу в поверхностной структуре, функция трансформируется на уровне глубинной структуры в сценарии, фреймы и составляющие их слоты. Двойственность функции и ее трансформация в диахронии и синхронии влечет изменение глубинного содержания сказки, которое напрямую зависит от временного фактора, потому что «время, пространство и число являются важнейшими концептами культуры. Это фундаментальные категории философии, естествознания, социологии, физики и других гуманитарных и точных наук» (Маслова 2005: 71). А.Я. Гуревич называет эти категории «,сеткой координат“, при посредстве которых люди воспринимают действительность и строят образ мира, существующий в их сознании» (Гуревич 1984: 30). Мы рассматриваем их как единственно постоянный элемент системы.

Изучение сказочного дискурса с точки зрения синхронии и диахронии перекликается с герменевтическими идеями, предложенными Х.Г. Гадамером. Сравните: «в действительности горизонт настоящего вовлечен в процесс непрерывного формирования, поскольку мы должны подвергать постоянной проверке все наши 
предрассудки. К подобной проверке не в последнюю очередь относится встреча с прошлым и понимание того предания, из которого исходим мы сами. Таким образом, горизонт настоящего формируется отнюдь не без участия прошедшего. Не существует никакого горизонта настоящего в себе и для себя, точно так же как не существует исторических горизонтов, которые нужно было бы обретать. Напротив, понимание всегда есть процесс слияния этих якобы для себя сущих горизонтов» (Гадамер 1988: 361).

Итак, изучение народных волшебных сказок в синхронии и диахронии позволяет проследить развитие сказочного сюжета во времени, выделить элементарные сюжеты и планы, найти их точки пересечения в пространственном развитии сказочного дискурса. В свою очередь, это позволяет понять цели и мотивы героев, которые определяют выбор того или иного сценария.

Рассматривая элементарные сюжеты поверхностной структуры и планы глубинной структуры в диахронии, можно проследить как развиваются параллельные миры сказочных героев, а, исследуя те же феномены в синхронии - выделить прецедентные слоты (например, числа и имена) и культурообусловленные сценарии.

\section{2. НАЦИОНАЛЬНО-КУЛЬТУРНЫЕ ОСОБЕННОСТИ ГЛУБИННЫХ СТРУКТУР НАРОДНЫХ ВОЛШЕБНЫХ СКАЗОК}

Поскольку при усвоении сказок происходит «переплетение коллективного, преломляемого через призму индивидуальности, и индивидуального, вкрапленного в коллективное» (Леонтович 2017: 252), рассмотрим основные функциональные элементы сказочного нарратива, выступающие в роли носителей культурно-специфической информации.

Согласно Ю.М. Лотману «наиболее резким проявлением человеческой природы является пользование собственными именами... Я и Другой - две стороны единого акта самосознания» (Лотман 2004: 17).

В народных сказках «имя» является текстообразующим элементом. Это основной носитель информации. Народное творчество обращалось к небольшому количеству имен, но именно они и создают определенный культурный пласт. В современном обществе имя собственное практически сведено к симулякру, «копии копий» (Платон), в сказках же это основной носитель информации. П.А. Флоренский полагает, что «имена можно отчасти сравнить с наследственными родовыми типами в генетике. Их нельзя точно определить, но раз усвоенные мышлением, они становятся незаменимыми; может быть, мы противились их усвоению, но, усвоив, легко убеждаемся, что именно с помощью их можем разбираться в тех сторонах явления, которые и составляют главное в нем, а между тем никаким перечнем признаков не могут быть уловлены и закреплены в мышлении» (Флоренский 2003: 31).

Не менее важным элементом сказочного нарратива и дискурса является числовой код народной волшебной сказки. Число как элемент особого культурного кода связывает поверхностную и глубинную структуры волшебных народных сказок. Оно определенным образом организует сказку на уровне поверхностной структуры, являясь одновременно основным элементом глубинных структур 
(этнокультурным маркером). Развитие сказочного сюжета всегда строится по определенным числовым моделям, универсальным матрицам на уровне поверхностной структуры, напоминая своего рода механизм гипноза: начав читать сказку, сложно остановиться, не дойдя до конца.

С другой стороны, на уровне глубинных структур числа активизируют социокультурные коды, приобщая читателя к сложному и противоречивому миру культурных ценностей определенной нации. Играя, сказка обучает, предлагая множество жизненных сценариев. Практически бессознательно читатели приобщаются к культурным архетипам, что позволяет им формировать необходимые культурологические модели поведения, которые являются наиболее релевантными в данном обществе.

Важно различать «число как сущее и как количество» (Плотин 1995: 452). На уровне поверхностной структуры числа связывают универсальную матрицу сказочного дискурса, организуя пространство и ритм. Например, числа три и семь очень часто определяют количество испытаний во время инициации главного героя:

"And the bread said, 'Little girl, little girl, take us out, take us out. We have been baking seven years, and no one has come to take us out", "then she met a cow, and the cow said, 'Little girl, little girl, milk me, milk me! Seven years have I been waiting, and no one has come to milk me"' (Jacobs 1890).

Даже волшебные помощники, помогая героине спастись от злой ведьмы, произносят число семь, как некое заклинание:

When the witch came up she said:

"Tree of mine, tree of mine,

Have you seen a girl

With a willy-willy wag, and a long-tailed bag,

Who's stole my money, all I had?"

And the apple-tree said, "No, mother; not for seven year" (Jacobs 1890).

Более того, в этой сказке помощники используют число семь дважды:

When the old witch came up, she looked about and said to the cow:

"Cow of mine, cow of mine,

Have you seen a girl

With a willy-willy wag, and a long-tailed bag,

Who's stole my money, all I had?"

And the cow said, "No, mother, not for seven year" (Jacobs 1890).

В русском же варианте отсутствует число семь:

— «Девушка, девушка, порви яблок»!

Бабина дочка ответила:

— «Мне некогда», — и побежала дальше.

Навстречу ей овечка:

- «Девушка, девушка, постриги меня»!

— «Мне некогда», — и побежала дальше.

Встретила свинку:

— «Девушка, девушка, потягай щетинки»!

— «Мне некогда», — и побежала дальше. 
Встретила коровку:

— «Девушка, девушка, подои меня»!

— «Мне некогда» и побежала дальше (Митропольская 1975: 140).

И.Я. Депман в своей книге «История арифметики» определяет семерку «как число, граничащее с несчитаемым», именно эта особенность, по его мнению, придавала числу ореол чудесности и являлась причиной возникновения суеверий: «француз дает самую сильную клятву словами: «крепко, как семь». У греков семь чудес мира, семь мудрецов. У реки Нил семь рукавов (на самом деле их гораздо больше). Счастливый чувствует себя на седьмом небе (считает себя «бесконечно» счастливым). Такое же происхождение и тот же смысл имеют русские пословицы и поговорки с числами семь: «У семи нянек дитя без глазу», «Семь раз отмерь, один отрежь», «За семь верст киселя хлебать», «Семеро одного не ждут». Во всех этих поговорках «семь» означает «много», когда-то, вероятно, означало «бесконечно много». Про непонятное мы и теперь говорим, что это книга «за семью печатями», а сказки повествуют о «семимильных сапогах». Знахарки в русских сказках дают больной «7 пакетиков с лечебной травой, которую надо настоять на 7 водах и в течение 7 дней принимать ежедневно по 7 ложек». Очевидно, что здесь вера в чудодейственную силу лечения опирается на многократно повторяемое число семь» (Депман 1959: 22).

"Now you have seen me, you shall see me no more, unless you are willing to serve seven years and a day for me, so that I may become a man once more".

"There is a stable seven miles long and seven miles broad, and it has not been cleaned for seven years, and you must clean it tomorrow, or I will have you for my supper".

“There's a lake seven miles long, and seven miles deep, and seven miles broad, and you must drain it tomorrow by nightfall, or else I'll have you for my supper".

"I've a worse job for you tomorrow; there is a tree, seven miles high, and no branch on it, till you get to the top, and there is a nest with seven eggs in it, and you must bring down all the eggs without breaking one, or else I'll have you for my supper" (Jacobs 1890).

Числа являются важной составляющей культуры, однако одно и то же число в поверхностной и глубинной структуре выполняет различные функции. Числа поверхностных структур организуют сказочный нарратив, в основе которого лежит категория времени. На этом уровне «наше сознание принимает число с тем готовым, но всего лишь воображаемым пространством, в котором каким-то образом размещены единицы числа. Это воображаемое пространство внутри чисел называется пространственностью» (Заренков 2007: 37).

На уровне глубинных структур числа раскрывают своё истинное значение, в терминах А.Ф. Лосева, обретают «эйдетический» смысл. Числа глубинных структур являются культурными маркерами, их можно сравнить с многоуровневыми образованиями, которые аккумулируют в себе основные национальные архетипы. Именно поэтому первое знакомство с волшебными народными сказками - это своего рода знакомство с культурными ценностями определенной нации. Эта идея находит подтверждение в результатах эксперимента, проведенного Э. Линди (Lindy 2006), в котором принимали участие англоязычные дети. После того как детям прочитали шотландскую народную сказку «Bruce and the Spider», их спро- 
сили: «Why did watching the spider give Robert the Bruce hope»? Большинство детей отметили, что именно седьмая по счету попытка паука дала надежду королю Шотландии победить короля Англии. Это число было «вычленено» ими из глубинной структуры сказочного дискурса.

В отличие от детей взрослые оставили без внимания столь яркий культурологический маркер, для этой группы участников эксперимента число семь было просто синонимом слову «много». Это в очередной раз доказывает, что дети наиболее восприимчивы к культурным маркерам глубинных структур.

Изучение особенностей волшебных сказок и их перевода с русского на английский и другие языки подтверждает мысль о том, что именно «текст является инструментом в процессе межкультурной коммуникации. При этом тексту перевода приходится «встраиваться» в новую парадигму: он оказывается элементом, принадлежащим одновременно двум системам - исходной культуре и культуре реципиента. Текст не только воздействует на реципиента, но и сам подвергается воздействию иной культуры» (Кондратенко 2011: 123).

Приведенные выше рассуждения вполне релевантны не только в отношении собственно текстов волшебных сказок, но и в отношении экранного воплощения последних. Покажем это на материале экранизаций волшебных сказок, предстающих как специфическая разновидность интерсемиотического перевода (см. Введение).

\section{3. «ВЕЧНЫЙ КРУГОСВЕТ, СКАЗОЧНЫЙ СЮЖЕТ - ЧУДОВИЩЕ И БЕЛЛЬ...»}

В силу очевидной необозримости количества волшебных сказок, созданных в отдельных культурах за всю историю человечества, сосредоточим наше внимание на фильмах, сюжетная линия которых в общих чертах воспроизводит волшебные сказки, объединенные единой темой, условно обозначенной «Красавица и чудовище». Отобранный нами корпус (13 кино- и телеверсий) включает художественные и анимационные фильмы, а также фильмы-мюзиклы:

Красавица и чудовище (х/ф, реж. Ж. Кокто, Франция, по мотивам сказки ЖанныМари Лепренс де Бомон «Красавица и чудовище» (La Belle et la Bête, 1757), 1946 год).

Аленький цветочек (мультфильм, реж. Лев Атаманов, СССР, по сказке С.Т. Аксакова «Аленький цветочек» (1858), 1952 г.).

Красавица и чудовище (мелодрама, реж. Филдер Кук, США, 1976 год).

Аленький цветочек (фильм-сказка, реж. И. Паволоцкая, СССР, по мотивам одноименной сказки С. Аксакова, 1977 г.).

Красавица и чудовище (фильм-мюзикл, реж. Ю. Марнер, Израиль/США, 1987 г.).

Красавица и чудовище (телесериал, реж. В. Лобл, Г. Триконис, 1987-1990 гг.).

Красавица и чудовище (мультфильм, реж. Г. Трусдейл, К. Уайз, США, по одноименной сказке Жанны-Мари Лепренс де Бомон, 1991 г., две премии Оскар).

Сказка о купеческой дочери и таинственном цветке (телефильм, реж. В. Грамматиков, по мотивам сказки С.Т. Аксакова «Аленький цветочек», 1991 г.).

Страшно красив (романтическая сказка / молодежное фэнтези, реж. Дэниэл Барнц, экранизация романа Алекс Флинн «Чудовище», США, 2011 г.).

Красавица и чудовище (телесериал, драматический триллер, реж. С. Гиллард, С.А. Эделсон, Р. Бота, Канада, 2012-2016 гг.). 
Красавица и чудовище (х/ф, реж. Кристоф Ганс, Франция, по книге ГабриэльСюзанны Барбо де Вильнев (Gabrielle-Suzanne Barbot de Villeneuve) «Красавица и чудовище» («La Belle et la Bête», 1740), 2014 год).

Он - дракон (романтическая сказка / фэнтези-мелодрама, реж. Индар Дженджубаев, экранизация романа супругов Т. и С. Дьяченко «Ритуал», Россия, 2015 г.).

Красавица и чудовище (фэнтезийно-музыкальный фильм, ремейк полнометражного анимационного фильма 1991 г., реж. Б. Кондон, США, 2017 г.).

Предварительная классификация приводимых выше фильмов позволяет подразделить последние на три группы. Группа 1 - фильмы-экранизации по мотивам сказки Габриэль-Сюзанны Барбо де Вильнев «Красавица и чудовище» («La Belle et la Bête», 1740 г.), более известной в сокращенном пересказе Жанны-Мари Лепренс де Бомон (1757 г.). Группа 2 - фильмы-экранизации по мотивам сказки С.Т. Аксакова «Аленький цветочек» (1858 г.), записанной писателем со слов его ключницы Пелагеи. Группа 3 - прочие фильмы, навеянные сюжетом «Красавицы и чудовища» и отвечающие запросам современной публики, которую привлекают триллеры и фэнтези. Наш анализ вполне логично будет касаться только двух первых групп фильмов из приведенного выше перечня как позволяющих провести корректное сопоставление экранного представления исходных волшебных сказок в структурном, культурологическом и интерсемиотическом планах.

В качестве основы для наших рассуждений примем понятие интерсемиотического перевода в терминах У. Эко (см. Введение). Аргументация ученого однозначно направлена на понимание трансмутации как интерпретации, где последняя выступает в качестве гиперонима по отношению к собственно трансмутации в терминах Р. Якобсона. Сравните: «Многие из очерков <... обращают наше внимание на то, сколь многоразличными и подчас плодотворными могут быть приключения в области трансмутации, то есть так называемого интерсемиотического перевода. Но мне больше по душе рассматривать их как бесконечные приключения в области интерпретации» (Эко 2006: 413).

В современном переводоведении термин «интерпретация» нередко ассоциируется с положениями интерпретативной теории перевода, лежащей в основе теоретических трудов последователей Парижской школы перевода (ESIT). Логика размышлений У. Эко, а также специфика нашего корпуса примеров позволяют распространить значение этого термина на экранное представление (экранизацию) текстов сказок с учетом возможностей кинематографа, что подтверждается последними изысканиями ученых в приложении к кинопроизведениям (Aumont 2015, 2017; Jullier 2012; Vanoye 2001, 2002). Интерпретация таких произведений с необходимостью требует освещения когнитивного аспекта, включающего как получение собственно информации (знание/содержание), так и когнитивных возможностей интерпретатора (прежде всего зрителя), обусловленных человеческой природой и объектом интерпретации (фильмом), представляющим собой синтез аудио-вербально-визуального. При таком концептуальном подходе на первый план выходит не собственно содержание, но креативные возможности интерпретатора. Полагаем, что весьма значимую роль при интерпретации кинематографического произведения с необходимостью играет нормативный аспект, понимаемый как 
«то, что считается общепринятым в данном языковом коллективе и на данном отрезке времени» (Ларина 2015: 159), что позволяет увязать интерпретацию с временем культуры в синхронии и диахронии.

В плане переводческом «художественный текст, трактуемый переводчиком как оригинал, уже является переводом, продуктом интерпретативной деятельности автора», то есть «перевод предстает как интерпретация интерпретированного» (Гарбовский 2008: 34). В случае экранизации литературных произведений в числе первых интерпретаторов «интерпретированного» с необходимостью оказывается режиссер фильма, от точки зрения которого зависит представление литературного произведения в его экранной форме, что объясняет появление все новых экранизаций последнего. По мнению исследователей, «за текстом (будь то текст литературно-словесный или кинотекст) всегда стоит целостная модель действительности (континуум), имеющая пространственно-временные характеристики. Этот художественный мир возникает в сознании творца в ходе создания им текста, и он же должен (в идеале) возникнуть в воспринимающем сознании в процессе эстетической коммуникации» (Седов 2016: 316) (курсив наш - В.Г., Н.Щ.). Как же обстоит дело в случае экранизации (тем более повторной!), рассматриваемой нами как разновидность интерсемиотического перевода (Горшкова, Лиханова 2016) или интерпретации исходного произведения? И какие культурно-обусловленные смыслы несет означенная интерпретация в зависимости от национальной принадлежности создателей фильма?

Стремление к новому прочтению оригинального текста (в нашем случае повторной экранизации), его повторной интерпретации может быть обусловлено несколькими причинами. Во-первых, стремлением показать другими средствами значимость оригинального текста. Такое стремление, как правило, сопряжено с критической составляющей и обусловлено желанием показать авторское прочтение/интерпретацию последнего. Заметим в этой связи отмеченные в научной литературе случаи обратного процесса, когда переводу на исходный язык подвергается текст на переводящем языке. В числе таковых фигурирует философскосатирический диалог Дени Дидро «Племянник Рамо», переведенный на французский язык с немецкого перевода Гете, поскольку оригинал произведения был на некоторое время утрачен. Во избежание двусмысленности французский переводовед Ж.-Р. Ладмираль называет такие случаи ретро-переводом (Ladmiral 2017: 21). И наконец, речь может идти о «переводе перевода», то есть об осуществлении перевода оригинального текста с уже существующего на отдельном языке. В терминах Ж.-Р. Ладмираля такой перевод квалифицируется как метаперевод (Там же).

На наш взгляд, в приложении к кино при экранизации сказки на первый план выходит диахронический аспект, влекущий за собой изменение упомянутой выше «целостной модели действительности». Меняются взгляды, отношения, эволюционирует язык. Меняется и сама кинематографическая реальность: прежние киноверсии устаревают в силу развития новых технологий, в частности, компьютерной графики, открывающей широкие возможности для представления возможных сказочных миров, живущих лишь в воображении их создателей. В подтверждение сказанного достаточно сравнить две французские версии анализируемой 
сказки 1946 и 2014 гг., вышедшие на экраны с разницей в неполные 70 лет! Примечательно, что в интерсемиотическом плане вторая версия может рассматриваться практически как ремейк фильма Ж. Кокто (своего рода метаперевод, если опереться на терминологию Ж.-Р. Ладмираля), на что указывает воспроизведение ряда мотивов последнего (руки, держащие канделябры, самостоятельно открывающиеся/закрывающиеся двери, появление/исчезновение роскошных яств на обеденном столе и т.д.). Но насколько более зрелищным, красочным и захватывающим предстает фильм К. Ганса благодаря используемым спецэффектам!

Однако в рамках настоящего исследования гораздо больший интерес представляет сопоставление интерпретации исходного сюжета сказки представителями разных культур, поскольку «для человека, сознание которого сформировано определенной лингвокультурой, ее мировоззренческие смыслы выступают как нечто само собой разумеющееся и обычно не осознаются вербально в качестве глубинных основ его мироощущения. Иная лингвокультура, напротив, отчетливо осознается человеком именно благодаря своей чуждости и настолько глубоко, насколько человек интересуется ее особенностями» (Новикова 2016: 257).

Обратимся к нашему материалу. Анализ фильмов-сказок показывает, что в структурном плане вне зависимости от принадлежности к той или иной культуре все означенные выше фильмы следуют известной схеме путешествия героя, прописанной признанными отечественными и зарубежными гуру сценарного дела Александром Талалом и Кристофером Воглером:

- «непростой ценностный выбор между собственным благополучием и судьбами других людей» (Талал 2018: 28);

- «[будь то миф, сказка или киносценарий] герой сталкивается с проблемой, с вызовом или чувствует потребность что-то предпринять. Он не может больше пребывать в комфорте своей обыденной жизни» (Воглер 2018: 50).

Соответственно, опираясь на наши рассуждения (Раздел 1), констатируем идентичность поверхностной структурной матрицы версий «Красавицы и чудовища» во всех экранизациях: отец семейства хочет сделать приятное своим дочерям и привести им желанные подарки (см. выше элементарный сюжет «добывание объекта» в терминах Б. Кербелите). Различаются лишь подарочные наборы и имена сестер, особенно это касается младшей дочери, которую в русских версиях зовут Настенька (1952 г.), Алена (1977 г.), Настя (1991 г.) и Белль во всех французских и американских экранизациях.

Полагаем, что заимствование как эквивалент французского антропонима Belle из первой экранизации является отражением интертекстуального характера экранного действа. Означенная интертекстуальность эксплицитно показана в версии 2017 г.: во-первых, действие американского фильма-сказки разворачивается во Франции (благодаря помощи волшебного зеркала Белль переносится в Париж, в каморку, в которой умирала мать, и узнает причину ее смерти), во-вторых, речь героев фильма постоянно пересыпается французскими вкраплениями, практически ставшими интернационализмами (рара, bonjour, pardon, bon voyage, adieu, mademoiselle, romantique, ragoût, soufflé, cabaret).

При достаточной однотипности последовательности элементарных сюжетов анализируемых фильмов-сказок сохраняется и содержание просьбы младшей 
дочери: в каждой фильме она просит привезти ей цветок. Но если в русских версиях речь идет о некоем «аленьком цветочке, краше которого нет на белом свете», во французских и американских это конкретный цветок - роза, желание получить которую объясняется разными причинами (мотивами). Так, Белль просит привезти розу, поскольку «здесь их нет» (1946 г.), «такую, какая росла в нашем саду» (1987 г.), потому что у нее «здесь ни одна не привилась» (2014 г.). Белль обожает розы, потому что таковые ей ежегодно привозит с ярмарки отец в память об умершей от чумы матери (2017 г.). И аленький цветочек, и роза становятся символами (средством) связи между зачарованным дворцом (Чудовищем) и родным домом (отцом), что не только позволяет героине волшебным образом перемещаться внутри сказочного нарратива, но и подтверждает ее стремление к целостности и полноценности семьи.

Как отмечают исследователи, «сказочные сюжеты и образы, несмотря на их фантастичность, достаточно легко отождествляются с реальными жизненными ситуациями и учат осознавать главнейшие истины человеческой жизни. В этом еще одна особенность сказки, относящаяся к универсалиям и придающая ей особую ценность» (Костикова 2015: 104).

Сопоставление экранных версий «Красавицы и Чудовища» на уровне поверхностной структуры демонстрирует универсальность характера младшей из дочерей, отличающейся мягкостью, покладистостью, беззаветной до самоотверженности любовью к отцу, заменившему сестрам мать. Белль не может смириться с жестоким наказанием отца за доставленную ей радость и без раздумий бросается в неизвестное, чтобы спасти ему жизнь. Особенно остро ситуацию с наказанием отца за сорванный цветок переживает Белль из фильма 2014 г.: «Матушка умерла, рожая меня...». А в фильме 2017 г. Белль буквально выталкивает отца из дворца, чтобы занять его место и тем самым спасти последнего, поскольку «когда дверь закроется, никто уже не войдет». Не менее глубока здесь и любовь отца: «Я не сберег твою маму и тебя я потерять не могу».

Что касается старших сестер, в русских версиях последние либо просто завистливы (1952 г.), либо переводят часы, чтобы отсрочить момент возвращения младшей сестры к Чудовищу, не понимая опасных последствий происходящего в силу своего юного возраста (1991 г.).

Достаточно легкомысленными предстают и многочисленные сестры и братья (их всего шестеро) во французском фильме 2014 г., обеспокоенные лишь тем, что из-за потери трех кораблей и гибели экипажей и товара их семья не сможет жить по-прежнему. В контексте сказанного выше любопытно, что во французской версии 1946 г. на первый план также выходит вопрос собственной безопасности и благополучия старших сестер, привыкших к спокойной и обеспеченной жизни в свое удовольствие. Так, они не хотят отпускать отца к Чудовищу из страха, что он не вернется, объясняя это следующим: «Отец, ты умрешь, а как мы выживем?».

На уровне глубинной структуры любопытна эволюция Чудовища. В принципе, страшное заклятие злой волшебницы, превратившей его в зверя, может быть снято лишь при одном условии - найти девушку, способную его полюбить. Означенная цель преследуется героем фильма с большей или меньшей эксплицитностью. Наиболее последовательным (и оттого наиболее жестоким!) предстает 
Чудовище в фильме Ж. Кокто (1946 г.). Сравните навязчивое: «Каждый вечер я буду задавать тебе один и тот же вопрос, станешь ли ты моей женой», на что следует неизменный ответ Белль: «Уходите, я не продаюсь!». Практически во всех версиях подчеркивается «звериная» природа Чудовища, запрещающего смотреть ему в глаза, но при этом оно само признается: «Спасти меня может только любящий взгляд» (1946 г.). Чудовище из версии 2014 г. также требует от Белль опускать глаза в его присутствии и не выходить из замка после захода солнца. В версии 1991 г. оно предупреждает: «Тот, кто увидит меня, ослепнет от ужаса!».

Совсем другим предстает Чудовище в фильме Б. Кондона (2017 г.), отличающегося целой россыпью режиссерских находок и, в первую очередь, ожившими предметами (канделябр, часы, гардероб, чайник, чашка), в которых волшебница превратила представителей двора надменного и себялюбивого принца и которые становятся полноправными участниками экранного действия, что значительно способствует раскрытию «волшебной составляющей» фильма-сказки. Чудовище Б. Кондона не стремится влюбить в себя Белль, напротив, всячески старается избавить ее от своего присутствия, несмотря на настоятельные советы придворных, очарованных девушкой. Сближение наших героев происходит на почве любви к литературе. Будучи дочерью изобретателя-отца, в этой версии Белль отличается недюжинными креативными способностями (достаточно вспомнить сконструированную ею стиральную машину, приводимую в действие осликом, который ходит по кругу вокруг бассейна!) и большой любовью к чтению. У Чудовища (зачарованного Принца) прекрасная библиотека, все книги которой он прочел. Наши герои проводят много времени за обсуждением последних.

В интерсемиотическом плане сближение героев отображается увеличением освещения: с каждой встречей темный и мрачный замок становится все светлее, начинают проглядывать лучи солнца, все ярче сияют глаза Принца, а на «лице» уменьшается количество растительности, сближавшей его облик с животным. По характеру он также намного мягче своих экранных предшественников и по мере возможности избегает насилия. Свидетельством этого является тот факт, что в отличие от всех других, Чудовище Б. Кондона отпускает Белль к отцу без всяких условий и практически без надежды снова стать человеком.

Примечательно, что в представлении королевского двора в фильме-сказке Б. Кондона находит отражение современная действительность: во-первых, несмотря на однотипные напудренные парики, среди придворных мы видим лиц всех национальностей и цветов кожи; во-вторых, один из героев отличается выраженной нетрадиционной ориентацией, что, впрочем, послужило основанием для полемики по поводу возможности/невозможности выпуска фильма на широкий экран и причиной присвоения последнему пометы «16+». Вышесказанное с очевидностью показывает определяющее влияние времени культуры на экранизацию волшебных сказок, выступающую как разновидность интерсемиотического перевода.

\section{4. ЗАКЛЮЧЕНИЕ}

Интерсемиотический перевод (трансмутация, интерпретация), концептуально восходящий к трудам Р. Якобсона и У. Эко, нечасто попадает в поле зрения исследователей в силу выраженного междисциплинарного характера. Вне зависи- 
мости от своей номинации означенный вид перевода заключается в интерпретации вербальных знаков знаками других семиотических систем. В качестве таковой в рамках данной статьи проанализирована экранизация волшебных сказок с опорой на конкретный алгоритм изучения сказочного нарратива, который позволяет совмещение лингвосемиотического и когнитивного анализа последнего в синхронии и диахронии. Показано, что в рамках семиотической системы сказочный нарратив отображается элементарными сюжетами поверхностной структуры, полностью совпадающими с планами глубинной структуры. Постулируется необходимость изучения планов последней с помощью фреймового анализа.

Проведенное исследование доказывает продуктивность предлагаемого алгоритма для исследования множественных экранизаций конкретных произведений, представляющих собой разновидность интерсемиотического перевода, понимаемого авторами как интерпретация, выводящая на первый план диахронический аспект в силу определяющего влияния времени культуры, что влечет за собой изменение «целостной модели действительности» в лингво-семио-культурологическом и собственно переводческом планах.

(C) Н.В. Щурик, В.Е. Горшкова, 2019

\section{СПИСОК ЛИТЕРАТУРЫ / REFERENCES}

Аникин В.П. Былины. Русские народные сказки. Древнерусские повести. М.: Детская литература. [Anikin, V.P. (1989). Byliny. Russkie narodnye skazki. Drevnerusskie povesti. Moscow: Detskaya literatura. (In Russ.).]

Воглер К. Путешествие писателя. Мифологические структуры в литературе и кино. М.: Альпина нон-фикшн, 2018. [Vogler, K. (2018). Puteshestvie pisatelia. Mifologicheskie strukturi $\mathrm{v}$ literature i kino. Moscow: Alpina non-fiction. (In Russ.).]

Гадамер Х.Г. Истина и метод: Основы философской герменевтики / Пер. с нем.; общ. ред. и вступ. ст. Б.Н. Бессонова. М.: Прогресс, 1988. [Gadamer, H.G. (1988). Istina i metod: Osnovy filosofskoy germenevtiki. Moscow: Progress. (In Russ.).]

Гарбовский Н. К. Отражение как свойство перевода. Вестник МГУ. Серия 22. Теория перевода. 2008. № 4. C. 26-36. [Garbovskiy, N.K. (2008). Otrazhenie kak svoistvo perevoda. Vestn. Mosk. un-ta. Ser. 22. Teoriya perevoda. № 4. 26-36. (In Russ.).]

Гегель Г.В.Ф. Феноменология духа. М.: Наука, 2006. [Hegel, G.W.F. (2006). The Phenomenology of Spirit. Moscow: Nauka. (In Russ.).]

Горшкова В.Е. Художественный кинодиалог vs документальный: жанровая специфика перевода. Вестник РУДН. Серия: Лингвистика. 2016. Т. 20. № 3. С. 243-259. [Gorshkova V.E. (2016) Khudozhestvennyi kinodialog vs dokumentalnij: zhanrovaya spetsifika perevoda. Russian Journal of Linguistics. T. 20. № 3. 243-259. (In Russ.).]

Горшкова В.Е., Лиханова В.В. Перевод семиотически осложненного текста: «Цветы для Элджернона» Дэниела Киза в романе и на экране. Вестник МГУ. Серия 22. Теория перевода. 2016. № 4. С. 67-80. [Gorshkova, V.E., Likhanova, V.V. (2016). Perevod semioticheski oslozhnennogo teksta: "Tzvety dlia Eldzhernona" Deniela Kiza v romane i na ekrane. Vestn. Mosk. un-ta. Ser. 22. Teoriya perevoda. № 4. 67-80. (In Russ.).]

Горшкова В.Е. Седьмая международная научная конференция «Русский язык и культура в зеркале перевода. Мировое кино: вчера, сегодня, завтра...», Афины, Греция, 28 апреля 3 мая 2017 г. Вестник РУДН. Серия: Лингвистика. 2017. Т. 21. o 4. С. 941—946. 
[Gorshkova, V. E. (2017) Sedmaya mezhdunarodnaya nauchnaya konferentsia Yazik I kultura v zerkale perevoda. Mirovoye kino: vchera, segodnya, zavtra..., Afiny, Gretsia, 28 april 3 may 2017. Russian Journal of Linguistics. № 4. 941 —946. (In Russ.).]

Гуревич А.Я. Категории средневековой культуры. М.: Искусство, 1984. [Gurevich, А.YА. (1984). Kategorii srednevekovoy kul'tury. Moscow: Iskusstvo. (In Russ.).]

Депман И.Я. История арифметики. М.: Изд-во Мин-ва просв. РСФСР, 1959. [Depman, I.Yа. (1959) Istoriya arifmetiki. Moscow. (In Russ.).]

Заренков Н.А. Слово, число и семиотическая теория жизни. М.: КомКнига, 2007. [Zarenkov, N.A. (2007). Slovo, chislo i semioticheskaya teoriya zhizni. Moscow: KomKniga. (In Russ.).]

Кербелите Б. Методика описания структур и смысла сказок // Типология и взаимосвязи фольклора народов СССР: Поэтика и стилистика. М.: Наука, 1980. 48-100. [Kerbelite, В. (1980). Metodika opisaniya struktur i smysla skazok. Tipologiya i vzaimosvyazi fol'klora narodov SSSR: Poetika i stilistika. Moscow: Nauka. (In Russ.).]

Комиссаров В.Н. Современное переводоведение. М.: ЭТС, 2001. [Komissarov, V.N. (2001). Sovremennoe perevodovedenie. Moscow: ETS. (In Russ.).]

Кондратенко Т.Л. Переводческий аспект английской сказки: проблемы сохранения и передачи национальной самобытности // Язык. Культура. Общение: Международная научно-практическая конференция «Международный фестиваль языков», Минск, 16 апреля 2011 г. Минск: Изд. центр БГУ, 2011. С. 121-124. [Kondratenko, T.L. (2011). Perevodcheskiy aspekt anglijskoy skazki: problemy sohraneniya i peredachi nacional'noy samobytnosti. YAzyk. Kul'tura. Obshchenie: Mezhdunarodnaya nauchno-prakticheskaya konferenciya «Mezhdunarodnyj festival' yazykov», Minsk, April, 2011. Minsk. (In Russ.).]

Костикова О.Ю. Истинностные и ценностные аспекты перевода сказки // Вестник Московского университета. Серия 22. Теория перевода. 2015. № 2. С. 100-113. [Kostikova, O.I. (2015). Istinnostnye i tsennostnye aspekty perevoda skaski. Vestn. Mosk. un-ta. Ser. 22. Teoriya perevoda. № 2. 100-113. (In Russ.).]

Ларина Т.В. Прагматика эмоций в межкультурном контексте // Вестник РУДН. Серия: Лингвистика. 2015. № 1. C. 144-163. [Larina T.V. (2015). Pragmatika emotsiy v mejkulturnom kontekste. Russian Journal of Linguistics. № 1. 144-163. (In Russ.).]

Леонтович О.А. «Зеркало, в котором каждый показывает свой лик»: дискурсивное конструирование идентичностей // Вестник Российского университета дружбы народов. Серия: Лингвистика. 2017. Т. 21. № 2. С. 247-259. [Leontovich, Olga A. (2017). “A Mirror in Which Everyone Displays their Image": Identity Construction in Discourse. Russian Journal of Linguistics, 21 (2), 247-259].

Лотман Ю.М. Семиосфера: Культура и взрыв. Внутри мыслящих миров. Статьи. Исследования. Заметки. СПб.: Искусство-СПБ, 2004. [Lotman, Yu.M. (2004). Semiosfera: Kul'tura i vzryv. Vnutri myslyashchih mirov. Stat'i. Issledovaniya. Zametki. St. Petersburg: Iskusstvo-SPB. (In Russ.).]

Лурия А.Р. Язык и сознание. М.: Изд-во Моск. ун-та, 1979. [Luriya, A.R. (1979). Yazyk i soznanie. Moscow: MGU Publ. (In Russ.).]

Маслова В.А. Когнитивная лингвистика. Минск: ТетраСистемс, 2005. [Maslova, V.A. (2005). Kognitivnaya lingvistika. Minsk: TetraSistems. (In Russ.).]

Митропольская Н.К. Русский фольклор в Литве. Исследования и публикация. Вильнюс: отд. «Сказки», 1975. [Mitropol'skaya, N.K. (1975). Russkiy fol'klor v Litve. Issledovaniya i publikaciya. Vilnius. (In Russ.).]

Новикова Т.Б. Социокультурная и лингвокультурная компетенция переводчика: развитие и совершенствование // Переводчик XXI века — агент дискурса / Под науч. ред. В.А. Ми- 
тягиной, А.А. Гуреевой. М.: ФЛИНТА: Наука. С. 255-260. [Novikova, Т.В. (2016). Soziokulturnaya i lingvokulturnaya kompetenziya perevodchika: razvitie I sovershenstvovanie. Perevodchik XXI veka - agent diskursa / Pod nauch. red. V.A. Mitjaginoi. Moscow: FLINTA: Nauka. 255-260. (In Russ.).]

Плотин. Сочинения. СПб.: Алтейя, 1995. [Plotin. (1995). Sochineniya. St. Petersburg: Alteya. (In Russ.).]

Пропп В.Я. Морфология волшебной сказки // Собрание трудов: Морфология волшебной сказки. Исторические корни волшебной сказки. М.: Лабиринт, 1998. С. 1-111. [ Propp, V.YA. (1998). Morfologiya volshebnoy skazki. Sobranie trudov: Morfologiya volshebnoy skazki. Istoricheskie korni volshebnoy skazki. Moscow: Labirint. 1-111. (In Russ.).]

Риордан Д. Народные сказки Британских островов; на английском языке. М.: Радуга, 1987. [Riordan, D. (1987). Narodnye skazki Britanskih ostrovov; na angliyskom yazyke. Moscow: Raduga. (In Engl.).]

Седов К.Ф. Общая и антропоцентрическая лингвистика. М.: Издательский Дом ЯСК, 2016. [Sedov, K.F. (2016). Obshchaya i antropozentricheskaya lingvistika. Moscow. (In Russ.).]

Талал А. Миф и жизнь в кино. Смыслы и инструменты драматургического языка. М.: Альпина нон-фикшн, 2018. [Talal, A. (2018). Mif I zhizn' v kino. Smysly i instrumenti dramaturgicheskogo yazika. Moscow: Alpina non-fiction. (In Russ.).]

Флоренский П.А. Имена. М.: АСТ, 2003. [Florenskii, P.A. (2003). Imena. Moscow: AST. (In Russ.).]

Хомский Н. Язык и мышление. М.: МГУ, 1972. [Chomsky, N. (1972). Language and mind. Moskow: MGU. (In Russ.).]

Раздобудько-Чович, Л.И., Чович Б. Об интеръязыковом и интерсемиотическом переводах как предпосылках для интермедиальных реализаций пьесы: от объекта словесно-эстетического к сценическому и к кинематографическому искусствам (на материале пьесы «Дядя Ваня» А.П. Чехова и ее перевода на сербский язык) // Вестн. Моск. ун-та. Сер. 22. Теория перевода. 2010. № 3. C. 27-40. [Razdobudko-Chovich, L.I., Chovich, B. (2010). Ob inter"yazykovom i intersemioticheskom perevodakh kak predposylkakh dlya intermedial'nykh realizatsii p'esy: ot ob"ekta slovesno-esteticheskogo k stsenicheskomu i k kinematograficheskomu iskusstvam (na materiale p'esy «Dyadya Vanya» A.P. Chekhova i ee perevoda na serbskii yazyk). Vestn. Mosk. un-ta. Ser. 22. Teorija perevoda. № 3.27-40. (In Russ.).]

Шлейермахер Ф. Академические речи 1829 года. URL: http://anthropology.ru/ru/text/ shleyermaher-fde/akademicheskie-rechi-1829-goda (дата обращения: 20.08.2018).

Щурик Н.В. Эволюция лингвистических взглядов на дискурс народной волшебной сказки // Вестник сибирского государственного аэрокосмического университета им. академика М.Ф. Решетнева. 2006. № 6 (13). 363-366. [Shchurik, N.V. (2006). Evolyuciya lingvisticheskih vzglyadov na diskurs narodnoy volshebnoy skazki. Vestnik sibirskogo gosudarstvennogo aehrokosmicheskogo universiteta im. akademika M.F. Reshetneva. № 6 (13). 363-366. (In Russ.).]

Эко У. Сказать почти то же самое. Опыты о переводе. СПб.: Symposium, 2006 [Eco, U. (2006). Skazat' pochti to zhe samoie. Opiti o perevode. SPb.: Symposium. (In Russ.).]

Якобсон Р. О лингвистических аспектах перевода // Вопросы теории перевода в зарубежной лингвистике. М.: Международные отношения, 1978. C. 16-24. [Jakobson R. (1978). $\mathrm{O}$ lingvisticheskikh aspektakh perevoda. Voprosi teorii perevoda $v$ zarubejnoi lingvistike. Moscow: Mezhdunarodnye otnosheniya Publ. 16-24. (In Russ.).]

Aumont, Jacques. (2015). L'analyse des films. 3-e édition entièrement refondue. Paris: Armand Colin.

Aumont, Jacques. (2017). L'interprétation des films. Paris: Armand Colin. 
Cassin, Barbara. (2016). Eloge de la traduction. Compliquer l'universel. Paris: Fayard.

Jacobs, Joseph. (1890) [Электронный ресурс] Celtic fairy tales. English fairy tales. More English fairy tales. URL: http://www.sacred-texts.com/neu/eng/meft/index.htm (дата обращения: 12.08.2018).

Jullier, Laurent. (2012). Analyser un film. De l'émotion à l'interprétation. Paris: Flammarion.

Ladmiral, Jean-René. (2017). La retraduction comme revendication de contextes intertextuels. Traductions et contextes, contextes et traduction / Sous la direction de Michaël Grégoire et Bénédicte Mathios. Paris : L'Hermattan. 19-31.

Lindy, Elaine L. (2006) [Электронный ресурс] Whootie Owl's Stories to Grow By. URL: http://www.storiestogrowby.com. (дата обращения: 12.08.2018).

Shchurik, Natalia V. (2017). The Translation of Proper Names in Folklore. Journal of Siberian Federal University. Humanities and Social Sciences, 10 (4), 591-597.

Taylor, John R. (1995) Linguistic Categorization. Prototypes in Linguistic Theory. Oxford: Clarendon Press.

Vanoye, François, Goliot-Lété, Anne. (2001). Précis d'analyse filmique. Paris: Nathan.

Vanoye, François. (2002). Récit écrit, récit filmique. Paris: Nathan.

\section{БЛАГОДАРНОСТИ}

Авторы выражают признательность анонимным рецензентам и редакторам выпуска за внимательное прочтение и ценные комментарии к данной статье.

\section{Article history:}

Received: 18 December 2018

Revised: 08 February 2019

Accepted: 15 March 2019

\section{История статьи:}

Дата поступления в редакцию: 18 декабря 2018

Дата принятия к печати: 15 марта 2019

\section{Сведения об авторах:}

ВЕРА ЕВГЕНЬЕВНА ГОРШКОВА - доктор филологических наук, профессор, профессор кафедры перевода и переводоведения факультета иностранных языков Института филологии, иностранных языков и медиакоммуникации Иркутского государственного университета, руководитель программы магистерской подготовки «Теория и практика письменного и основы устного перевода», член Союза переводчиков России. Сфера научных интересов: теория и практика перевода, аудиовизуальный перевод, профессионально-ориентированный перевод, дидактика перевода, межкультурная коммуникация, французский язык.

Контактная информация: e-mail: gorchkova_v@mail.ru, prof.gorchkova@yahoo.fr

НАТАЛЬЯ ВИКТОРОВНА ЩУРИК — кандидат филологических наук, доцент, зав. кафедрой перевода и переводоведения факультета иностранных языков Института филологии, иностранных языков и медиакоммуникации Иркутского государственного университета. Сфера научных интересов: теория и практика перевода; манипуляция в переводе, экология перевода, дидактика перевода, межкультурная коммуникация.

Контактная информация: e-mail: amistad@yandex.ru 


\section{Bionotes:}

VERA E. GORSHKOVA is Doctor of Philology, Professor at the Department of Translation and Translation Studies, Irkutsk State University, Course Director of the Master Program "Theory and Practice of Translation and Basic Principles of Interpretation", Member of the Union of Translators of Russia. Research Interests: Theory and Practice of Translation, Audiovisual Translation, Profession-Oriented Translation, Didactics of Translation, Intercultural Communication, French.

Contact Information: e-mail: gorchkova_v@mail.ru, prof.gorchkova@yahoo.fr

NATALIA V. SHCHURIK is Ph.D., Associate Professor, the Head of the Translation and Translation Studies Department, Irkutsk State University. Research Interests: Theory and Practice of Translation, Manipulation in Translation, Ideology and Translation, Profession-Oriented Translation, Didactics of Translation, Intercultural Communication.

Contact Information: e-mail: amistad@yandex.ru 